International Journal of Instruction e-ISSN: 1308-1470 • www.e-iji.net

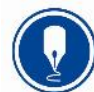

January $2022 \bullet$ Vol.15, No.1

p-ISSN: 1694-609X

pp. $197-218$

Article submission code:

20201205175630

Received: $05 / 12 / 2020$

Revision: 15/06/2021
Accepted: 10/07/2021

OnlineFirst: 17/10/2021

\title{
Pedagogia Dictionary: Web Application Development
}

\section{Rudi Susilana}

Universitas Pendidikan Indonesia, Indonesia, rudi_susilana@upi.edu

\section{Gema Rullyana}

Universitas Pendidikan Indonesia, Indonesia, gemarullyana@upi.edu

\section{Ardiansah}

Universitas Pendidikan Indonesia, Indonesia, ardiansah@upi.edu

\section{Yayu Wulandari}

Universitas Pendidikan Indonesia, Indonesia,yayuwulandari26@gmail.com

This study aimed to develop a web-based Pedagogia Dictionary application, which is a special dictionary in the field of education and learning. This research was conducted using the D \& D (Design and Development) approach or development research that produces a product. This study adopted the stages of the Ellis \& Levy (2010) development model consisting of: a) identification of the problem; b) explain the purpose; c) design and develop artifacts; d) testing artifacts; e) evaluating test results, f) communicating test results. The information system modeling used a system through diagrams consisting of flowcharts, data flow diagrams, and entity relationship diagrams. In this study, the questionnaire was used to collect data related to the product that had been designed. The web based Pedagogia Dictionary application is expected to improve the quality of learning at Universitas Pendidikan Indonesia. In further development studies, the Pedagogia Dictionary application can be developed using mobile-based web technology. The findings have implications for the availability of a web-based dictionary as a reference source on the concept content in the fields of education and learning. The development of this application is in accordance with the development of the water fall model system. The usability testing results are a series of product trial results showing that there are several recommendations from respondents. So it can be concluded that the product is good to be an information search system in the form of a pedagogical dictionary dictionary.

Keywords: pedagogia, dictionary, webbased, education, learning

\section{INTRODUCTION}

The use of web technologies by such groups and organizations may affect the organizational structure and the process of institutionalization. (Eimhjellen, 2014).

Citation: Susilana, R., Rullyana, G., Ardiansah., \& Wulandari, Y. (2022). Pedagogia dictionary: Web application development. International Journal of Instruction, 15(1), 197-218. https://doi.org/10.29333/iji.2022.15112a 


\begin{abstract}
Almost all community activities have been touched and helped by web technology. For example, some sectors that use web technology include education and learning facilities, communication facilities, entertainment facilities, economic and business facilities, information retrieval facilities and so forth. The presence of increasingly sophisticated web technology certainly has a big impact on people's lives and one of the impacts that is easily seen is the need for fulfilling information and data (Bughin, et al., 2011). Linked data was a data publishing technique used on the World Wide Web to connect related data for the purpose of accessibility on the Web. Linked data are based on hypertext transfer protocol (HTTP), uniform resource identifiers (URI) and using Semantic Web standards such as the resource description framework (RDF) which allows related data to be connected with each other and with other related resources as well (Haslhofer and Isaac, 2011). Link allows fast transfer through the information room. Links must be well designed so that they contribute to the use of electronic dictionaries (Pernice, 2014). Various types of links can be used in an electronic dictionary. Internal links (links to pages on the same site) can be used to direct users to other words / items that they want to find or other interesting information that is presented. External links (links to pages on different sites) can be used to direct more information outside the dictionary (Heid et al., 2012).
\end{abstract}

Results of similar studies to confirm the accuracy of the selection some programs which supported product development The findings of this study showed that participants expressed positive attitudes and perceptions toward the use of the mobile dictionary in "Educational Readings in English" course and in learning new vocabularies. They are also eager to use it in other courses and outside the classroom when teaching and helping other siblings (Barham, 2017). The use of dictionaries is a great help in vocabulary learning and nowadays the emergence of electronic dictionaries has added a new and valuable resource for vocabulary learning. (Rezaei \& Davoudi, 2016). Considering the fact that the use of electronic dictionaries will be indispensable in the near future, the study would have direct implications for the successful implementation of computer assisted language learning (CALL) and effective use of electronic dictionaries in EFL contexts. (Dashtestani, 2013). Electronic dictionaries have become more and more attractive, accepted and popular to EFL learners at different levels, using electronic dictionaries in EFL classroom has gradually become an alternative to many. As for teachers, helping students tap into electronic dictionaries effectively is one of the best ways to help them become independent, lifelong language learners. (Zheng \& Wang, 2016)

The field of education and learning certainly needs to adjust to the current transformation of the industrial revolution in order to meet the needs, especially the content (material) needs that support learning activities. Content in the field of learning has a variety of types, including: facts, concepts, procedures, processes and principles (Kemdikbud, 2013). The advancement of information communication technology (ICT) has not only affected our lifestyle but also the educational system (Almekhlafi \& Abulibdeh, 2018). Collection of references that are more specific are needed to meet the needs of users. Reference collections containing certain information will provide answers to certain questions. Types of reference collections are very diverse, and the 
most common ones include encyclopedias, dictionaries, atlases. Dictionary is a type of reference book that explains the meaning of words. A dictionary functions to help someone in getting to know new words. Dictionary as a starting point for an activity to find out clear definitions and the exact meaning of a term. At this time dictionary has both conventional and electronic types. Conventional dictionaries are printed materials while electronic dictionaries were first produced by Japan in 1979 with the name pocket electric translating machine. The change then presents various types of dictionaries. Commonly known types of dictionaries are complete dictionaries, bilingual dictionaries, monolingual dictionaries, and special dictionaries or terms. Specialized dictionaries or terms contain information about common words, but with certain arrangements, for example educational and learning dictionaries. Although printed dictionary allows users to find interesting terms and enrich vocabulary, the search process takes a long time. This dictionary of education and learning terms certainly wants to be developed in such a way. Based on preliminary studies to students in the faculty of education at Universitas Pendidikan Indonesia (UPI), it was found that some students still find it difficult to find reference terms in the field of education and learning. There are also those who say that opening a printed dictionary is quite complicated and time-consuming. The next statement stated that at the moment the online information search is preferred by students rather than using printed information sources. Based on considerations after discussing with several parties such as students, lecturers, and instructors, online references need to be developed in order to meet the information needs, especially in the fields of education and learning.

Therefore, the researcher intends to develop a dictionary of pedagogical terms in the form of a website. The web-based application developed by researchers has the technical form of a web with an interface that can attract users. In conducting the web development process the researchers used several support systems. Researchers carry out several processes which include pre-production, production processes, and postproduction web development which cover the research flow process. Some support programs include the use of development component packages integrated in one installer. One of the alternatives that can be used is XAMPP, an application package that makes it easy to install PHP, Apache Web Server and MySQL. In addition, XAMPP is equipped with various other facilities that will provide convenience in developing a website. In the production process, of course, some analysis of hardware and software requirements are needed. The software requirements cover what needs to be implemented in the web development. Web programming using the XAMPP application package compiles the programming languages to be used, namely html, php and css. Then, phpMyAdmin is used in managing the mysql database that can be accessed.

The current conditions create opportunities for researchers by developing web-based pedagogical dictionaries in the fields of education and learning. Universitas Pendidikan Indonesia as one of the teacher colleges (Educators and Educational Personnel Institutions) which has a graduate profile of producing qualified teachers of course must be ready to answer the challenges of the industrial revolution 4.0. Product-oriented research that can improve the quality of the university certainly becomes one of the strategies that can be taken to achieve a full institutional vision. Furthermore, the use of 
information technology in education and learning also follows the challenges of the industrial revolution 4.0 at this time so that positive endeavors must always be pursued so that the university is always leading in the field of education and learning. To achieve this, the development of Pedagogia web-based dictionary is expected to be a primary source of concept content in the fields of education and learning.

\section{Theoretical Background}

With the amount of information available, more tools that can help people to access relevant information quickly become increasingly important. An example of an information tool that can meet user information needs is an electronic dictionary. As crucial self-learning tools, dictionaries have many different types considering their language basis and design. Regarding their language basis, there are monolingual dictionaries which present the explanations in the target language and bilingual dictionaries which provide explanations in native-to-target or target-to-native languages. (Takkaç Tulgar, 2017). Electronic media is a different (and relatively new) medium where dictionaries are available. The development of information technology has made it possible to increase or add dictionaries that were not necessarily possible before and has led to many dreams and discussions about the ideal dictionary that can provide access to only relevant information while withholding irrelevant information (Ball \& Bothma, 2018). The next section will consider several technologies that can be applied to electronic dictionaries.

There are numerous mobile apps available free of cost that libraries can recommend to users such as apps for reading, research and reference, taking notes and writing, content creation, social media, communication, etc. (Sawant, 2017). These phases are: (1) Assessing degrees of word knowledge, (2) Accessing new word meanings, (3) Archiving new information for studies, (4) Analyzing word parts and origins, (5) Anchoring new words in short-term memory, (6) Associating words in related groups for long-term retention, (7) Activating words through productive written or oral use, and reviewing, recycling, and retesting vocabulary items (Loucky, 2010). As more technology is added to the system, usability becomes increasingly important.

The usability evaluation criteria that were discussed in this paper have adapted the general web usability evaluation criteria to be specifically relevant to e-dictionaries and will make it possible to evaluate e-dictionaries, and assist lexicograph "herswith the development of e-dictionaries by pointing to the ideal e-dictionary" (Ball \& Bothma, 2018). Likewise, there are many free dictionary applications (categorized in Books \& References on the Play Store) available through the Google Play Store; most of them have annoying notifications, poor performance and low ratings. Among 100 free applications, two very useful and authentic dictionaries, e.g. The Oxford English Dictionary is only available in online mode and the Dictionary by Merriam-Webster is available even in offline mode but sometimes requires internet if there is pronunciation. Library professionals can recommend that users have it on their mobile devices. These dictionaries have a reputation of authenticity for 200 years and were developed by renowned contributors and editors. The search and learning tools can greatly help users as shown in the following pictures. 


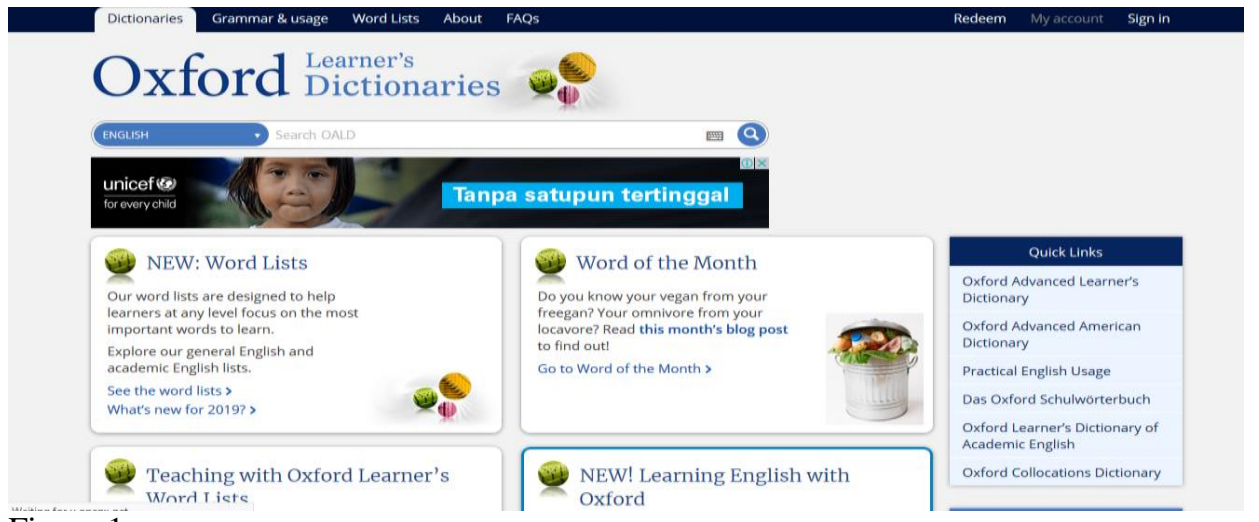

Figure 1

Oxford dictionaries

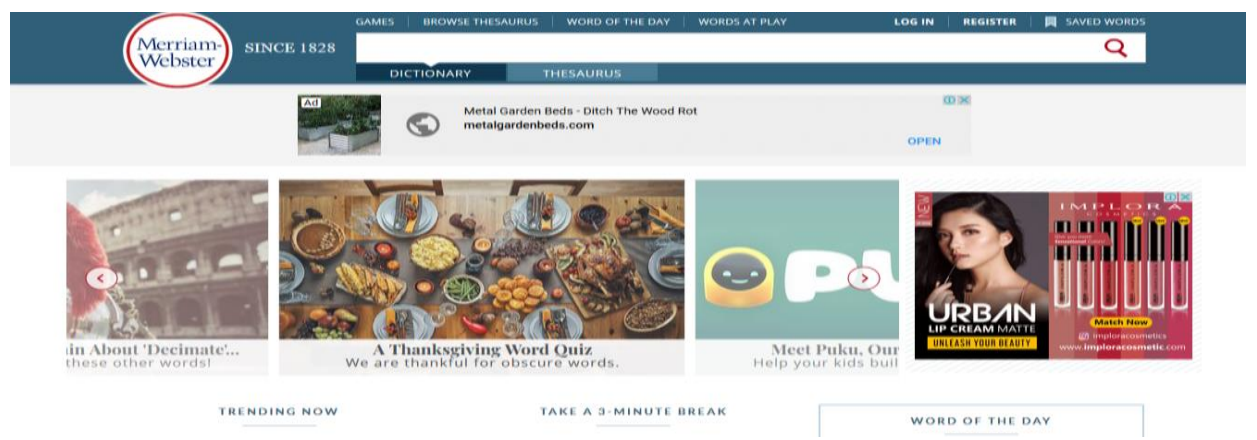

Figure 2

Merriam webster dictionaries

The most important access facility in E-Dictionaries is connecting. The link can be an internal dictionary or an external dictionary. The type of dictionary-internal link that is most reminiscent of a printed dictionary is a cross reference, from which a mouse click will take the user to where the nomination is given. However, E-Dictionaries offer many other possible internal links, for example (Svensen, 2009):

1. Displays in a separate window.

2. Link to a particular entry by clicking on the relevant lemma when it appears in another entry.

3. Link to a specific meaning by clicking on it in the window where the lemma structure polysemy is displayed in the shape diagram.

4. Link to other dictionary components that may offer, including: audio pronunciations, semantic lists of related words, images, supporting a definition, choice of examples that are displayed using words in the relevant meaning, etc.

The process of developing information systems for the web-based dictionary used the waterfall method. a software engineering method. According to Pressman (2012, p. 39) 
the waterfall model is a classic model that is systematic, sequential in building software. Meanwhile, according to Sommerville (2011), the stages of the waterfall method requirements analysis and definition, system and software design, implementation and unit testing, integration and system testing, operation and maintenance. The development of the waterfall method in this study followed several sequential stages:=: requirements analysis, system design coding \& testing, program implementation, and maintenance. The stages are explained below.

1) Requirement definition is the stage of determining the analysis of needs made in order to produce products that are made can be understood by users and developers. This stage includes determining the analysis of hardware and software requirements at the development stage.

2) System and software design are the stages of system planning that determine the overall system architecture. The stages in this study include database design and interface design and navigation structure that will be created.

3) Implementation and unit testing (coding) which is the stage of implementing the database in making a hosting will be used, namely in an XAMPP software package that includes a database management application called phpMyAdmin. In this study in order to facilitate researchers in web development, the researchers chose XAMPP as a web development package that includes database and server. As stated by Nugroho (2010, p. 1) XAMPP is a complete web programming package that can be used to learn web programming, especially PHP and MySQL. XAMPP, a free software which supports many operating systems, is a compilation of several programs.

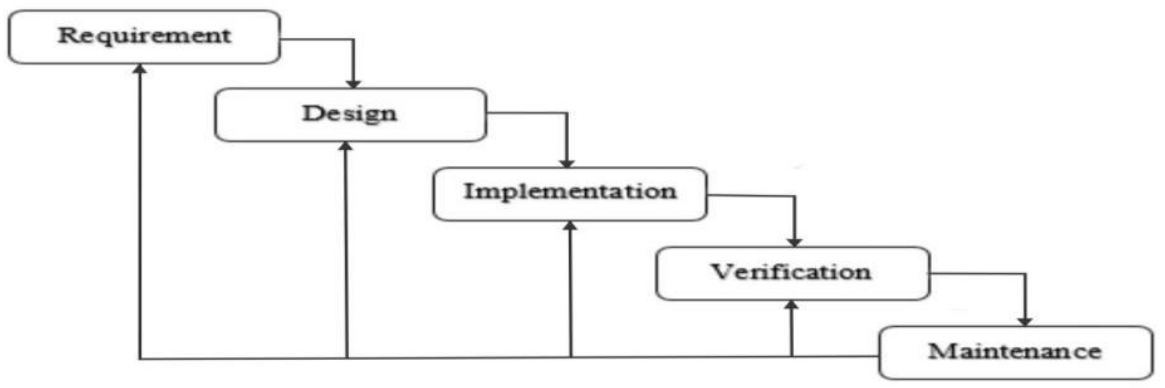

Figure 3

Model waterfall (Pressman, 2012)

Based on the model, the XAMPP programming package can be easily used because there are a number of support systems to run the application and it is also easy to learn from the viewpoint of the navigation system of the system.

4) Verification is the stage of application by testing each unit to uncover errors that occur. In this study the system test design was carried out by carrying out black-box testing. This test is one of software testing that focuses on functional software.

5) Operation and maintenance were carried out after the software developed. Maintenance includes correcting errors that were not found in the previous step. The 
improvement of system unit implementation and improvement of system services was also conducted on Pedagogia Dictionary

\section{METHOD}

This research focuses on developing web-based systems. The study was conducted at Indonesia University of Education. The research design is the stages that the researcher carried out in conducting research. The method in This research used Design and Development $(\mathrm{DnD})$ method which prioritizes the process and product. Richey \& Klein (2014) defines Design and Development method as, "The systematic study of design, development and evaluation processes with the aim of establishing an empirical basis for the creation of instructional and noninstructional products and tools and new or enhanced models that govern their development. " Design and development planning is a way to build or create knowledge based on systematic data from the application of a product. The focus of this research is more directed at product development, namely Pedagogia web-based dictionary

\section{Research Subjects}

This study involved participants consisting of several experts. Where there are three categories of participants, namely web practitioners, content experts and 10 people for education experts. The assessment in this case is used to find out how good an interactive web is according to web practitioners by Dadi Mulyadi, M.T. The content expert's assessment was used as a research instrument to find out how well and what should be included in the web product content by Dr. Isah Cahyani and assessments by 10 education experts were used as one way to determine the quality of using a webbased pedagogic dictionary.

\section{Data Collection}

Instruments In this study, the questionnaire was used to collect data related to products that had been designed. By using a questionnaire, researchers can find out things that still need to be improved and that have been good to be presented through the product. Questionnaire preparation refers to the grid, where the grid made by the researcher has several types among them in terms of the expert's judgment. In its manufacture, the questionnaire was developed by researchers and an Expert Judgment process was carried out by several experts.

\section{Research design}

The Design and Development method was carried out in several stages: a) Identify the problems; b) Describe the objectives; c) Design and develop the artifact; d) Test the artifact; e) Evaluate the results of testing; and f) Communicate the testing results.

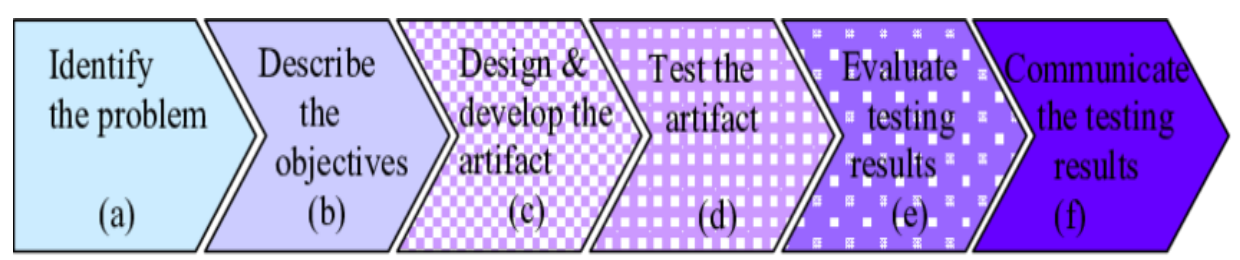


The Design and Development method must be done with a good design. The stages in this method include a) Identify the problems; b) describe the objectives; c) design and develop the artifact; d) test the artifact; e) evaluate the results of testing, f) communicate the testing results.

At this stage the researcher identifies the problem that is the background for conducting research on the development of the web-based Pedagogia Dictionary application. The results of problem identification concluded by the researcher that:

1. Concept content in the field of education and learning sourced from primary references such as dictionaries is still lacking.

2. Online primary reference sources for concept content in the field of education and advocacy have not been available so far.

3. The use of primary references, especially printed dictionaries, is considered impractical at this time (digital era) by students (especially in universities).

The second stage of the method of design and development method is to determine the development objectives. By establishing development objectives, the development process will be more focused so that it does not go off track or become too widespread. The purpose of this development itself is: To produce a web-based pedagogic dictionary product. In developing the design, researchers started to build and develop a web-based librarian dictionary. the software development model used is a waterfall.

The researcher conducted a limited trial to obtain data by: 1 . The product validation stage for web practitioners, this process includes an assessment test to test whether this product is in accordance with user needs with the criteria of a good website. 1) Usability, that is, users can operate it properly and easily; 2) Web navigation system, namely navigation that contains a web interface design that is easy to learn, consistent, supports user goals and behavior, also provides clear visual messages, 3) Graphic design that has good layout, color, shape and typography, 4) Content that is useful for target users is also content that must be relevant to the goal, 5) Compability, which is compatible with various devices such as browsers, 6) loading time, namely the speed of web appearance, 7) Funcionality is how well a web works from a technological aspect, usually involving programming language , 8) Accessibility to load web pages that can be accessed by users; 9) interactivity is .hyperlinks (link) and feed back mechanism.

Product validation stage for content experts, this stage the writer provides a review process to education content experts to test whether this product is in accordance with the education content needs with the alignment coverage of web design with objectives, the scope of detailed information to be conveyed, web design maturity, as well as opportunities in the future in attracting interest. The instrument used is to use the ideal dictionary criteria according to namely entry completeness, alphabetical arrangement systematics, information on word origins.

Product validation stage which includes usability testing of the product. The instrument used is usability testing. 1) Learnability is a usability of a web that is easy to learn; 2) Efficiency, namely efficient use of a web; 3) Memorability of a web with easy to 
remember usability; 4) Errors, does the website have a low error rate, 5) Satisfaction is user satisfaction in using the web.

\section{Analysis Data}

The process of calculating the percentage in this study was carried out by comparing the frequency of the results with the expected frequency. The calculation is carried out using the equation formula 1 as follows:

$$
\text { Percentage }=\frac{\text { obtained frequency }}{\text { the expected frequency }} \times 100 \%
$$

The results of the data obtained through the Likert scale in the form of numbers are then adjusted to the Likert scale category as follows:

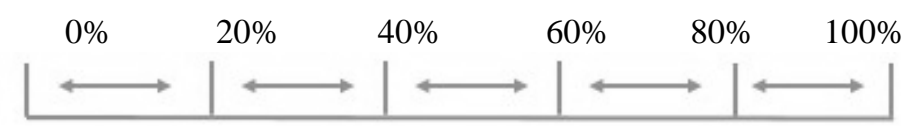

Based on the existing scale categories, the percentages obtained can be grouped as follows:

\begin{tabular}{lc}
\multicolumn{2}{c}{ Percentage scale } \\
\hline \multicolumn{1}{c}{ Web Quality Category } & Persentase \\
\hline Very good & $81-100 \%$ \\
Good & $61-80 \%$ \\
Fair & $51-60 \%$ \\
Poor & $25-50 \%$ \\
Bad & $0-20 \%$ \\
\hline
\end{tabular}

\section{FINDINGS AND DISCUSSION}

The results are presented and discussed in the order of the research questions (RQs).

\section{Identify the problem}

At this stage the researcher identifies the problem that is the background of the research on the development of Pedagogia web-based Dictionary application. The results of the identification of problems concluded by the researchers are the followings.

1. Concept content in education and learning sourced from primary references such as dictionaries is still lacking.

2. Primary reference sources based on online concept content in the field of education and advocates so far is not yet available.

3. The use of primary references by students (especially in tertiary institutions).

4. Especially printed dictionaries is considered to be impractical at the moment (digital era) The collection of information in this study was conducted through a preliminary study in which online questionnaire was distributed to 5th semester students in each study program within the Faculty of Education. In addition to the questionnaire, there were interviews with several parties such as lecturers in the Faculty of Education and 
librarians at the UPI central library. Based on the results of a preliminary study that refers to questionnaires and interviews, researchers found a variety of information that became the central background in the implementation of Pedagogia web-based dictionary research and development, leading to the needs analysis formulated below.

Table 1

Field study results

Field Study Results The solution

At present, most students in tertiary institutions are Credible online learning resources digital immigrants and digital natives.

Concept content in education and learning sourced from Primary reference sources such as primary referrences is considered to be still limited. dictionaries

The use of primary reference sources, especially printed A technological approach that can dictionaries, is considered less practical at this time provide practicality in the process of (digital era).

Primary reference sources such as online-based searching for concept content.

Primary reference sources of dictionaries are considered important and will be useful dictionaries on educational and for students, especially in understanding the content of learning need to be packaged concepts in the field of education and learning according to current learners' practices.

\section{Describes the objectives}

In this step, the research objectives were formulated based on the results of the preliminary study. Researchers analyze the objectives by taking into account the needs of students, lecturers and librarians. These objectives are as follows.

Table 2

Field study results

\begin{tabular}{ll}
\hline Needs & Objectives \\
\hline Credible online learning resources. & $\begin{array}{l}\text { Students are more interested and motivated to } \\
\text { access learning resources. }\end{array}$ \\
\hline $\begin{array}{l}\text { Primary reference sources such as } \\
\text { dictionaries. }\end{array}$ & $\begin{array}{l}\text { Students can access primary reference sources, } \\
\text { especially dictionaries. }\end{array}$ \\
\hline a technological approach that can provide & $\begin{array}{l}\text { Students are more practical in accessing primary } \\
\text { practicality in the process of searching for } \\
\text { refence sources especially dictionaries on } \\
\text { concept content. }\end{array}$ \\
\hline $\begin{array}{l}\text { Primary reference sources of dictionaries on } \\
\text { educational and learning need to be }\end{array}$ & $\begin{array}{l}\text { Developing Pedagogia web-based Dictionary } \\
\text { application as a primary reference source on the } \\
\text { packaged according to current learners' } \\
\text { practices.a }\end{array}$ \\
\hline
\end{tabular}

\section{Design and Development}

At this stage, researchers conducted 2 stages, namely system development and content development design

\section{System Development}


Table 3

Hardware and software requirements

\begin{tabular}{llll}
\hline Hardware & & Software & \\
\hline Requirement & Specification & Requirement & Specification \\
\hline PC & Processor i7 & Operating system & \\
& Harddisk 500Gb & & \\
& RAM 4 Gb & & \\
& VGA 2 Gb & & PHP \\
& Hub/Switch & Programming Language & HTML \\
& Router & & \\
\hline & Access Point & & XAMPP \\
& & Database Engine & Apache \\
\cline { 3 - 4 } & & Web Server & Mozilla Firefox \\
\cline { 2 - 4 } & & Web Browser & Notepad ++ \\
\hline
\end{tabular}

2. System and Software Design

System planning that determines the design of the database and the design of the navigation structure which is intended as a step to implement the system to be made. This section describes the structure of the system design that will be created using flowcharts, data flow diagrams, entity relationship diagrams, and interface design.

\section{a) Flowchart}

Flowchart is a chart that determines the process of an activity and implementation in an organization or system that will be created. The following is a flowchart of some important features in the application to be more detailed. Here is a flowchart of the main view of the website:

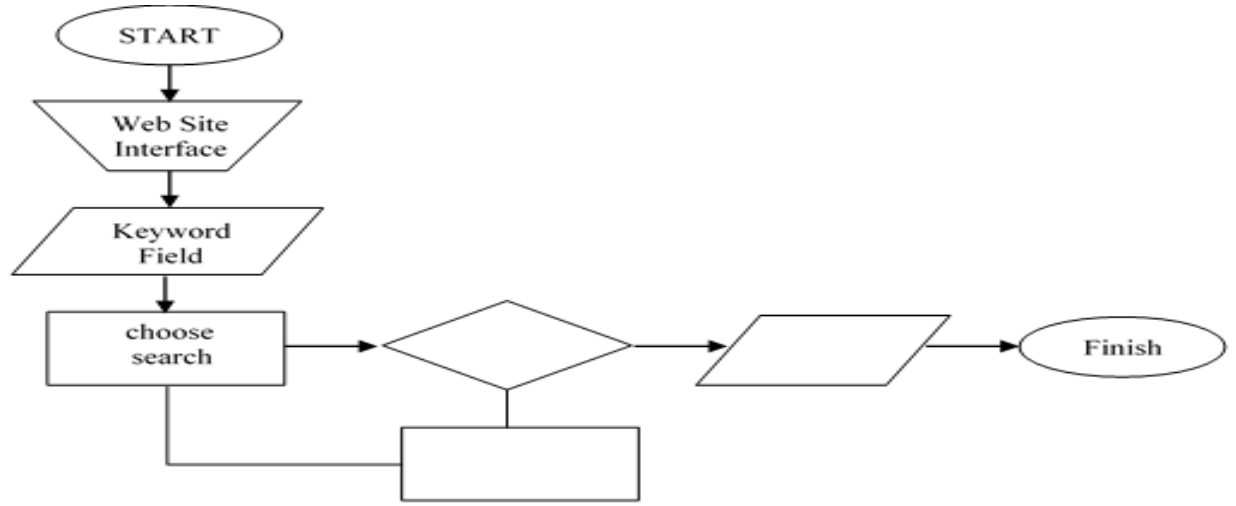

Figure 4

Start page flowchart

The flow on the start page starts from the user accessing the Pedagogia Dictionary system, then proceeds to filling in the keyword field, selecting search to process the word searched and then finding whether the word searched exists or not. If the word exists the search results will display but if it does not it means the word has not been inputted by the admin then the search process is declared complete. 


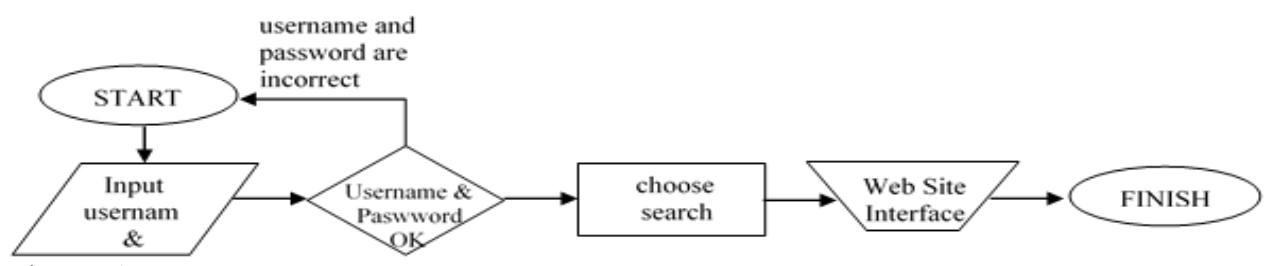

Figure 5

Login flowchart

The login flow starts from the admin typing in the username, password. Then the program will check the user database if the username and password match. If the username, password is incorrect, the page will return to the login page. If the username, password match, the admin will successfully log in and can enter the dashboard page. Then the flowchart is used by the admin to process word input, user input and team profile settings.

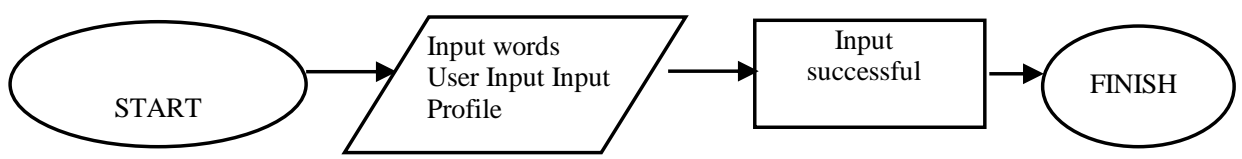

Figure 6

Flowchart dashboard

The flow for admin or dashboard management starts from word input, user input and profile input then the process is successful.

\section{b)DFD (Data Flow Diagram)}

Data flow diagrams are a network of processes with data storage and are connected to one another or a collection of symbols that describe the system data flow. Data Flow Diagrams (DFD) show structured data flow. In DFD, input and output data are described according to each process in the system. To explain each process along with its input and output, DFD is divided into several levels so that the explanation can be done in detail. 


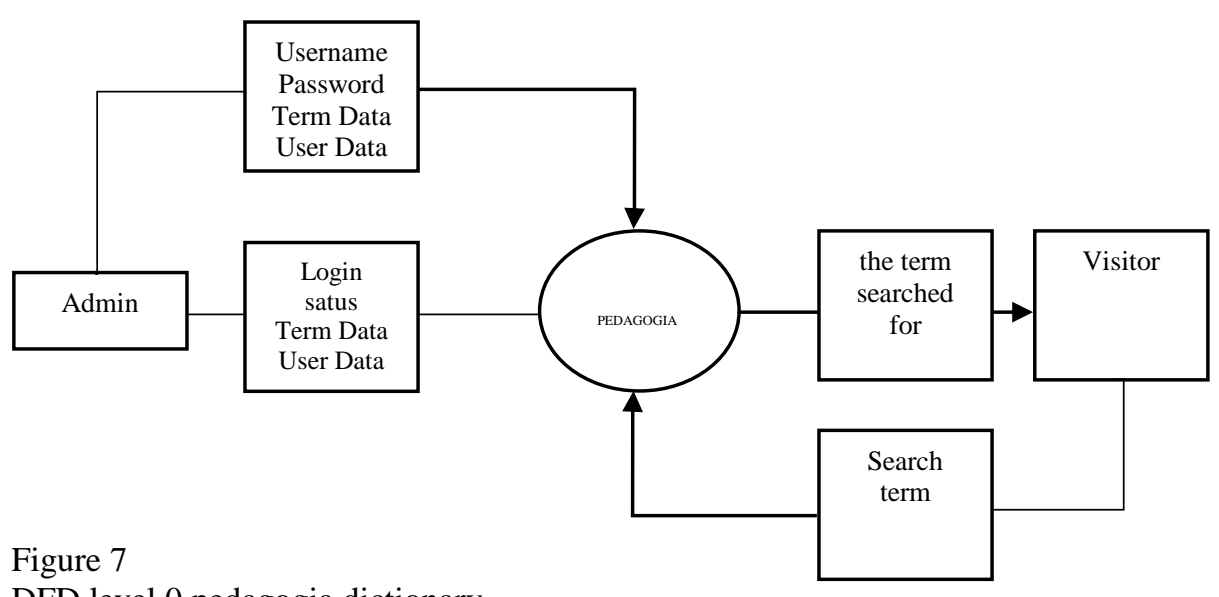

DFD level 0 pedagogia dictionary

Description of Data Flow Diagram (DFD) Level 0 is as follows:

1. Admin process, data obtained from the website are login status, dictionary data, user data and profile data.

2. The visitor process, the data obtained from the website is the term information sought.

c) Interface Design

This design has several stages including the program structure, admin dashboard design and the main page in development. The program structure that is designed consists of the forms that will be created ascan be seen in the image below.

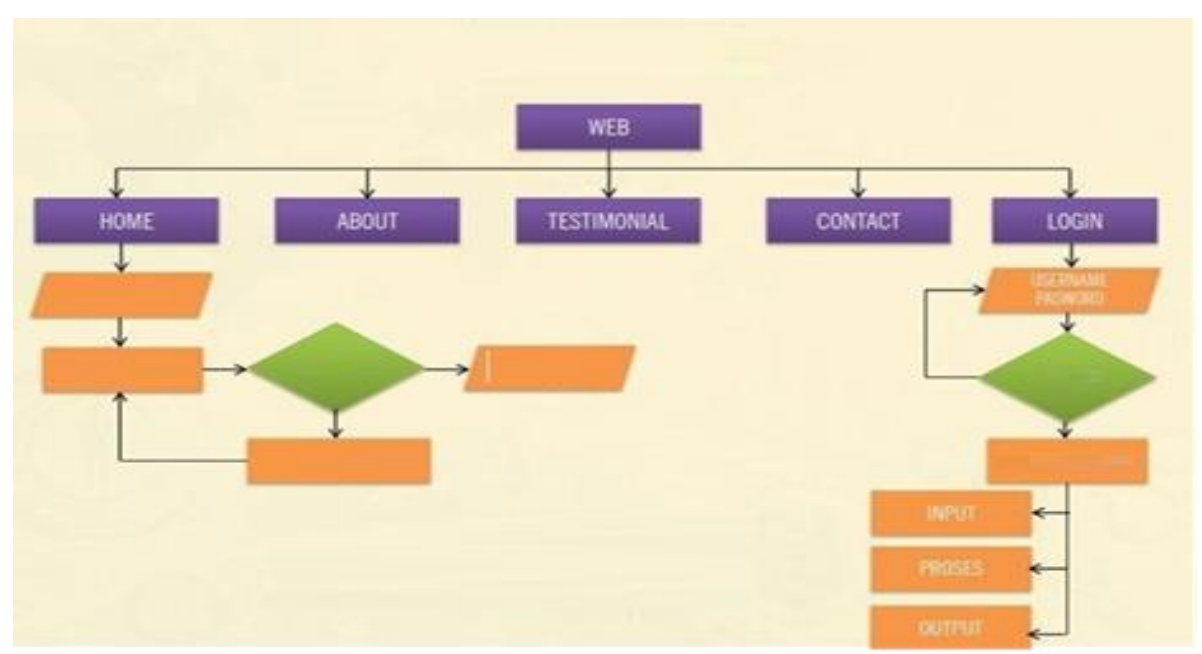

Figure 8

Program structure

International Journal of Instruction, January 2022 •Vol.15, No.1 


\section{Implementation}

The stages of making the application must refer to the design made in accordance with the original purpose of development and the application can perform functions that are in accordance with the requirements of the user as well as the manager. In general, this website was developed using the programming language Hyper Text Markup Language (HTML) and Hypertext Prepocessor (PHP), which is collaborated with the programming language display manager or web interface design namely Cascading Style Sheets (CSS). The layout header design, footer, menus, dashboard and other elements of this website were first designed by Mindjet software after which it was converted into web layout programming lines using the Notepad ++ programming language development software.

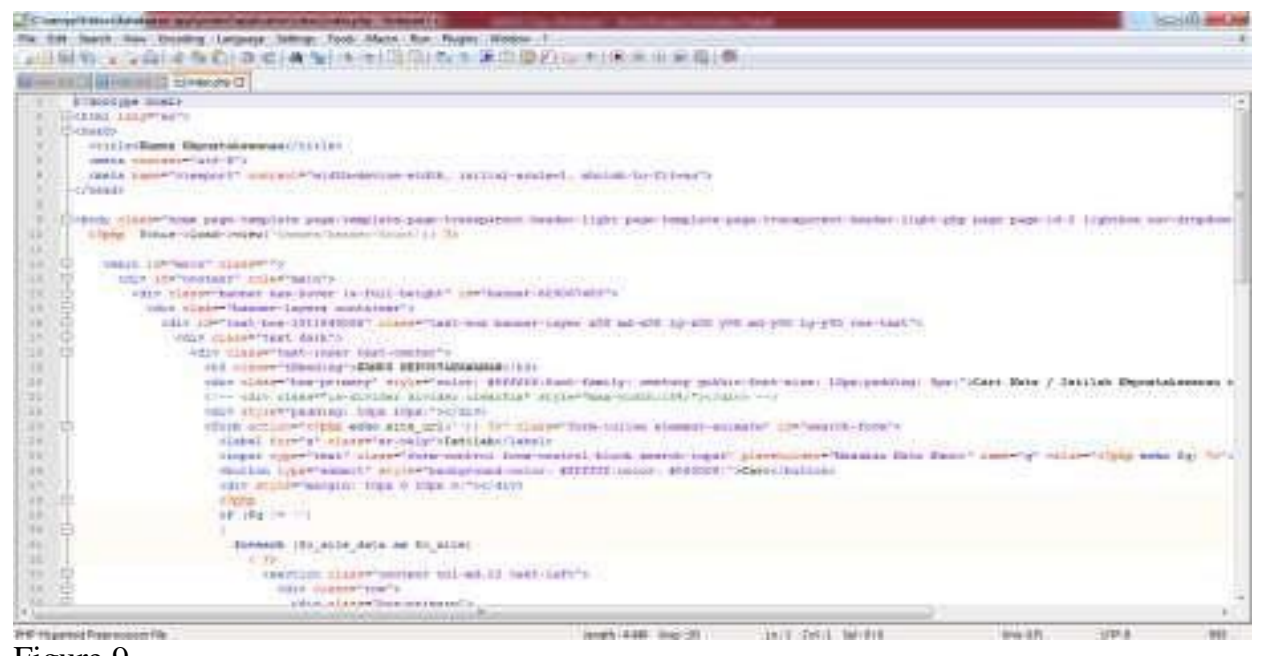

Figure 9

Coding PHP main page using notepad ++

The picture above is a PHP code on the main page which makes the main page view by connecting the dictionary database that has been inputted. When finished, the results of the conversion using Notepad ++ were then trialed on browsers such as Google Chrome and Mozilla Firefox to again make improvements and views that can be adjusted. 


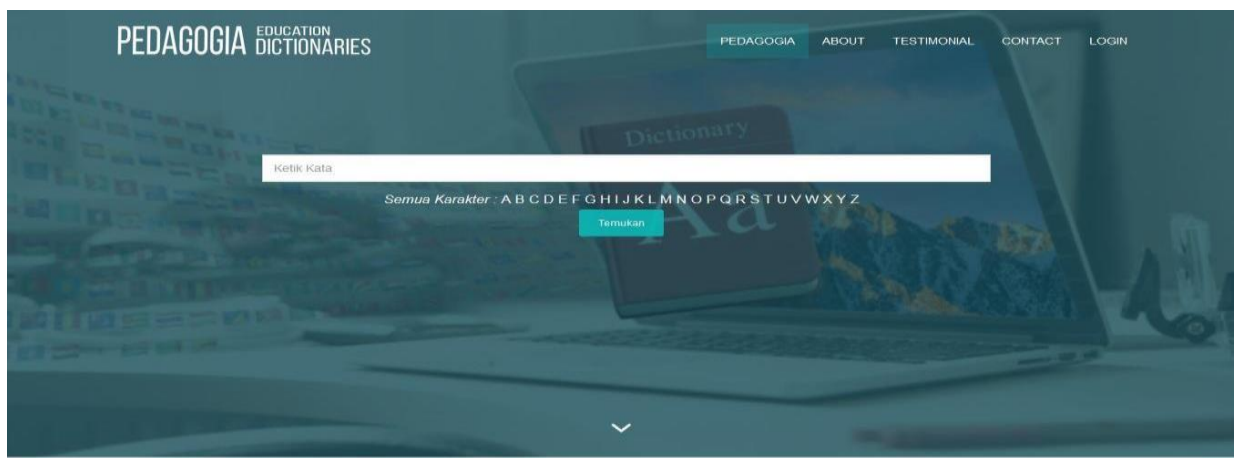

PEDAGOGIA EDUCAIION
DICTIONARIES Pedagoga $\quad$ About $\quad$ Testimonial $\quad$ Contact LoGIN

AGUNAN

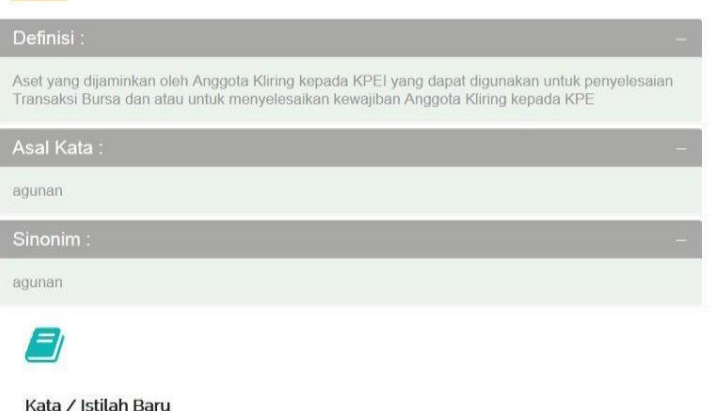

Kata / Istilah Baru
\#

Kata / Istilah yang sering digunakan

Lorem ipsum dolor sit amet, consectetur adipiscing elit, sed

lo eiusmod tempor incididunt ut labore et dolore magna

요

Jadilah Bagian Kami

Lorem insum dolor sit amet consectetur adipisicing
eit sed to eususmod tempor incididunt ut labore et

dolore magna aliqua.

H

Yang Gambar Bendera?

ABOUT

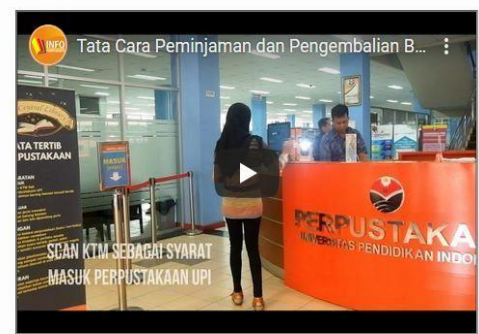

It's something important you want to know.

Lorem ipsum dolor sit amet, consectetur adipisicing elit sed do eiusmod tempor incididunt ut labore et Ut wisi enim ad minim veniam, quis nostrud

It's something important you want to know.

Lorem ipsum dolor sit amet. consectetur adipisicing elfit, sed do eiusmod tempor incididunt ut labore et. Ut wisi enim ad minim veniam, quis nostrud.

Figure 10

Testing the web display using the Mozilla Firefox browser

International Journal of Instruction, January $2022 \bullet$ Vol.15, No.1 


\section{a) System Testing}

The web-based dictionary system testing used black box testing method. The test results can be seen in the table below.

Tabel 4

Blackbox testing

\begin{tabular}{|c|c|c|c|c|}
\hline Item Test & Testing & Expected Results & Test Result & Conclusion \\
\hline Page front & $\begin{array}{l}\text { Entering words "Agunan" } \\
\text { inside search column }\end{array}$ & $\begin{array}{l}\text { Appear explanation agunan } \\
\text { below search column }\end{array}$ & $\begin{array}{l}\text { Appear explanation } \\
\text { collateral below search } \\
\text { column }\end{array}$ & $\mathrm{OK}$ \\
\hline Page front & $\begin{array}{l}\text { Enter a word that Not } \\
\text { inputted yet in the search } \\
\text { field }\end{array}$ & $\begin{array}{l}\text { Do not appear explanation } \\
\text { in bottom of the column }\end{array}$ & $\begin{array}{l}\text { Do not appear explanation } \\
\text { in bottom of the column }\end{array}$ & OK \\
\hline Page front & Click the Pedagogia logo & $\begin{array}{l}\text { The front page of the web } \\
\text { appears }\end{array}$ & $\begin{array}{l}\text { The front page of the web } \\
\text { appears }\end{array}$ & OK \\
\hline Page front & $\begin{array}{l}\text { Click the top menu } \\
\text { "Home" }\end{array}$ & $\begin{array}{l}\text { The front page of the web } \\
\text { appears }\end{array}$ & $\begin{array}{l}\text { The front page of the web } \\
\text { appears }\end{array}$ & OK \\
\hline Page front & $\begin{array}{l}\text { Click the top menu About } \\
\text { Us }\end{array}$ & $\begin{array}{l}\text { A page about us appears } \\
\text { which covers the guarantor } \\
\text { answer, team compiler and } \\
\text { the developer application. }\end{array}$ & $\begin{array}{l}\text { A page about us appears } \\
\text { which covers the } \\
\text { guarantor answer, team } \\
\text { compiler and the } \\
\text { developer application. }\end{array}$ & OK \\
\hline Login & $\begin{array}{l}\text { Username and The } \\
\text { password is not filled }\end{array}$ & $\begin{array}{l}\text { Page appears Username and } \\
\text { password wrong }\end{array}$ & $\begin{array}{l}\text { Page appears Username } \\
\text { and password wrong }\end{array}$ & $\mathrm{OK}$ \\
\hline Login & $\begin{array}{l}\text { Username password filled } \\
\text { in }\end{array}$ & Page appears dashboard & Page appears dashboard & OK \\
\hline Dashboard & $\begin{array}{l}\text { Input filled words, } \\
\text { fragments and terms not } \\
\text { filled }\end{array}$ & $\begin{array}{l}\text { Appear description field is } \\
\text { required }\end{array}$ & $\begin{array}{l}\text { Appear description field } \\
\text { is required }\end{array}$ & OK \\
\hline Dashboard & $\begin{array}{l}\text { Input words, fragments, } \\
\text { terms in content }\end{array}$ & $\begin{array}{l}\text { Successfully inputted, a list } \\
\text { of words that have been } \\
\text { input appears }\end{array}$ & $\begin{array}{l}\text { Successfully inputted, a } \\
\text { list of words that have } \\
\text { been input appears }\end{array}$ & $\overline{\mathrm{OK}}$ \\
\hline Dashboard & $\begin{array}{l}\text { Enter the word library in } \\
\text { the word list search field }\end{array}$ & $\begin{array}{l}\text { A list related to the library } \\
\text { appears }\end{array}$ & $\begin{array}{l}\text { A list related to the library } \\
\text { appears }\end{array}$ & $\mathrm{OK}$ \\
\hline Dashboard & $\begin{array}{l}\text { Click the "edit" menu word } \\
\text { list }\end{array}$ & $\begin{array}{l}\text { A fragment word editing } \\
\text { page also appears }\end{array}$ & $\begin{array}{l}\text { A fragment word editing } \\
\text { page also appears }\end{array}$ & OK \\
\hline Dashboard & Click the delete menu & $\begin{array}{l}\text { Words that have been } \\
\text { inputted are deleted }\end{array}$ & $\begin{array}{l}\text { Words that have been } \\
\text { inputted are deleted }\end{array}$ & OK \\
\hline Dashboard & $\begin{array}{l}\text { Inputting Username, } \\
\text { password not filled }\end{array}$ & $\begin{array}{l}\text { Appear description field is } \\
\text { required }\end{array}$ & $\begin{array}{l}\text { Appear description field } \\
\text { is required }\end{array}$ & $\mathrm{OK}$ \\
\hline Dashboard & $\begin{array}{l}\text { Inputting Username, } \\
\text { password not filled }\end{array}$ & $\begin{array}{l}\text { The user list page that has } \\
\text { been input appears }\end{array}$ & $\begin{array}{l}\text { The user list page that has } \\
\text { been input appears }\end{array}$ & $\mathrm{OK}$ \\
\hline Dashboard & $\begin{array}{l}\text { Click the "edit" menu user } \\
\text { list }\end{array}$ & $\begin{array}{l}\text { A fragment word editing } \\
\text { page also appears }\end{array}$ & $\begin{array}{l}\text { A fragment word editing } \\
\text { page also appears }\end{array}$ & OK \\
\hline Dashboard & $\begin{array}{l}\text { Click the "delete" menu } \\
\text { user list }\end{array}$ & $\begin{array}{l}\text { Words that have been } \\
\text { inputted are deleted }\end{array}$ & $\begin{array}{l}\text { Words that have been } \\
\text { inputted are deleted }\end{array}$ & OK \\
\hline Dashboard & $\begin{array}{l}\text { Inputing the name of the } \\
\text { drafting team / developer } \\
\text { not filled }\end{array}$ & $\begin{array}{l}\text { Appear description field is } \\
\text { required }\end{array}$ & $\begin{array}{l}\text { Appear description field } \\
\text { is required }\end{array}$ & OK \\
\hline Dashboard & $\begin{array}{l}\text { Input the name of the } \\
\text { drafting team / developer } \\
\text { filled }\end{array}$ & $\begin{array}{l}\text { A team list page that has } \\
\text { been inputted appears }\end{array}$ & $\begin{array}{l}\text { A team list page that has } \\
\text { been inputted appears }\end{array}$ & OK \\
\hline Dashboard & $\begin{array}{l}\text { Click the "edit" menu team } \\
\text { list }\end{array}$ & $\begin{array}{l}\text { The word fragment edit } \\
\text { page appears too term }\end{array}$ & $\begin{array}{l}\text { The word fragment edit } \\
\text { page appears too term }\end{array}$ & $\mathrm{OK}$ \\
\hline Dashboard & $\begin{array}{l}\text { Click the "delete" menu } \\
\text { team list }\end{array}$ & $\begin{array}{l}\text { Words that have been } \\
\text { inputted are deleted }\end{array}$ & $\begin{array}{l}\text { Words that have been } \\
\text { inputted are deleted }\end{array}$ & $\mathrm{OK}$ \\
\hline
\end{tabular}

International Journal of Instruction, January $2022 \bullet$ Vol.15, No.1 


\section{b) Limited Trial}

The product validation stage includes an assessment test to test whether this product is in accordance with users' needs with good website criteria according to Suyanto (2009, pp. 61-69). Furthermore, for product validation from content experts, the author provides a judgment process for content experts in the field of education and learning to evaluate whether this product fits the needs of educational and learning content and aligns with the objectives, coverage of detailed information to be delivered, web design maturity, as well as future opportunities in attracting interest. The instrument used the ideal dictionary criteria according to Chaer (2007), consisting of the completeness of entries, systematic arrangement in alphabetical order, information on the origin of words.

Assessment by web practitioner's assessment of the website was carried out by Dadi Mulyadi, MT, lecturers and ICT expert. The assessment included the aspects of good web criteria, namely usability, navigation system, graphic design, content, compatibility, loading time, functionality, accessibility, and interactivity. The assessor gives a score of 54 , which is equal to $84 \%$ in percentage. This means the website fulfilled the standards to be used as a web based electronic dictionary. The following is the assessment record of several components reviewed.

Table 5

Assessment of web criteria by web practitioner

\begin{tabular}{lll}
\hline Aspect & Score Obtained & Maximal Score \\
\hline Usability & 13 & 15 \\
\hline Navigation System & 4 & 5 \\
\hline Graphic Design & 12 & 15 \\
\hline Content & 4 & 5 \\
\hline Compatibility & 4 & 5 \\
\hline Loading Time & 5 & 5 \\
\hline Functionality & 4 & 5 \\
\hline Accessibility & 4 & 5 \\
\hline Interactivity & 4 & 5
\end{tabular}

Total Score 54

Maximum Number of Scores 65

Percentage $84 \%$

1. Usability: Interface and tools are easy to use, predictable and attractive, which make it easy for users to access the website.

2. Navigation system: Familiar and consistent so that it is easy to use.

3. Graphic design: Typography (type of size and font) used as well asthe design of controls and presentation formats to accommodate users are good.

4. Content: Web content is good. 
5. Compability: Compatible with a variety of devices and browsers that support it is good because the website can already be accessed in browsers such as Mozilla Firefox, Google Chrome, Internet Explorer, or Opera.

6. Loading time: Speed display is very good.

7. Funcionality: The use of a new programming language in creating a dynamic web is already good.

8. Accessibility: The web can be accessed by everyone

9. Interactivity:, Users' engagement indicates good interactivity.

There is also suggestion to make the system user friendly so that access to information is easy. The system that is made should use standard meta data so that it can be integrated with existing systems and it is not difficult if the data is shared with other institutions.

\section{Trial Stage}

At this stage, the product that has been produced is then tested on a predetermined target. This stage performs usability testing to determine the level of usability of the website from the user's side. Respondents for this trial are library staff and librarians from various institutions.

\section{Test Results}

In this step, the pilot phase carried out by the researcher involved 10 students. The trial aims to find out the opinion of the target, related to the product that has been designed by applying it to the target. In the testing process, students were given an online assessment questionnaire related to five aspects of usability testing: learnability, efficiency, memorability, errors, and satisfaction. Then the questionnaire was filled in after respondents accessed the website. The data obtained from the assessment questionnaire are the responses of the respondents, which are then made in the form of scores so that they can be averaged and converted into percentages as follows:

Table 6

Website trial assessment results

\begin{tabular}{llll}
\hline Aspect & Score Obtained & Maximal Score & $\%$ \\
\hline Learnability & 147 & 200 & $73 \%$ \\
\hline Efficiency & 77 & 100 & $77 \%$ \\
\hline Memorability & 71 & 100 & $71 \%$ \\
\hline Errors & 80 & 100 & $80 \%$ \\
\hline Satisfaction & 119 & 150 & $79,3 \%$ \\
\hline
\end{tabular}

Total Score 494

Maximum Number of Scores 650

Percentage $76 \%$

The average score of the five aspects evaluated was $76 \%$ which belongs to the good category. The learnability aspect scored $73 \%$ which indicated that the web content was 
quite easy to navigate, study and understand. The efficiency in accessing the web-based dictionary was $77 \%$ while the memorability was $71 \%$. The errors aspect was $80 \%$ which means that the occurrence of errors was low. The last aspect assessed was satisfaction, which scored at $79.3 \%$ indicating that it was comfortable for users to use the website.

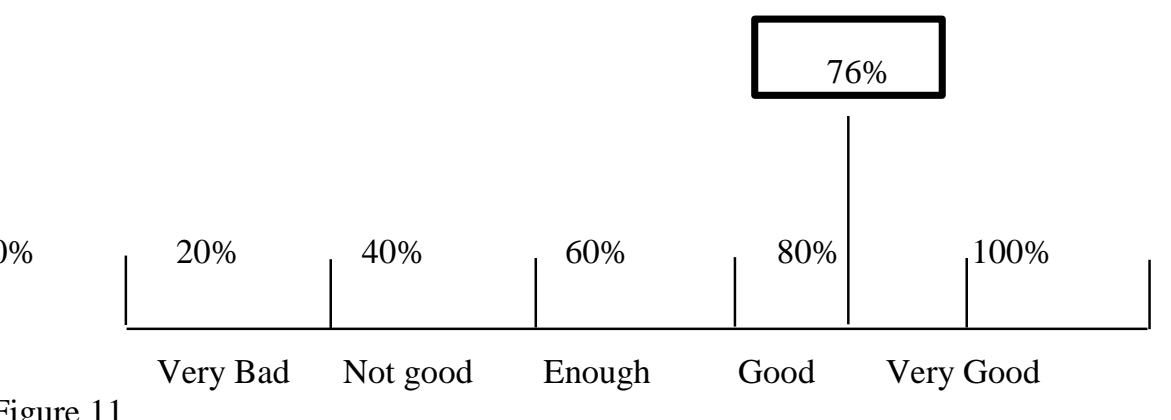

Average respondents of educational experts

The five aspects assessed shows that the Pedagogia dictionary website is feasible to be used as one of the information sources for pedagogical and as an alternative to learning.

System strengths, weaknesses and recommendations

The data on strengths, weaknesses and recommendations are based on the questionnaire filled out by library staff.

Strengths

1) Interface is user friendly, simple, and easy to understand.

2) Can be developed to support the world of library science education

3) Overall is good

4) Effectively helps search for pedagogical terms

5) Can facilitate learning

6) Help the librarian in understanding library terms

7) Simple, good

8) Display is simple and easy to use

9) Can make it easier for UPI students to search for words

Weaknesses

1) Not yet able to enter, the features are still lacking, need to be improved

2) There are still words that cannot be searched

3) Search results are not satisfactory 
4) There is no statement if the word searched is not in the database

Recommendations

1) As a slight improvement in the user interface to reflect education and be more interesting, bibliographic data of the terms used and the equivalent English words will be included.

2) Added with more terms.

3) The writing of the word "Search" should be enlarged

4) There should be notification or statement if the word being searched does not exist so users will not-question whether the application is error or simply incomplete.

5) Add a browse menu based on the alphabet so that novice users who want to explore have direct access to the terms related to education and learning.

6) The search feature needs to be improved because not all the words entered are there, it should be simpler and more practical, and it should be clear whether the dictionary is specialized for UPI students or general public.

\section{CONCLUSION}

Based on the results of the analysis and discussion in this study, it can be concluded that the development stages of the web-based pedagogical dictionary consists of design, development and product trials. At the firststage, to achieve good design, several steps are carried out, including identification of problems, formulation of objectives. Researchers conducted a preliminary study in the form of a questionnaire to meet these steps, so that the resulting data can then be set forth in the next stage, namely design development. Second. At the design development stage, researchers chose the software engineering model, namely the waterfall model. These steps include software requirements analysts, system design such as interface database design, implementation using XAMPP, an application that contains the management of a system using html, php, css programming using notepad ++ applications as well as mysql database with phpMyadmin, after the next implementation process black box testing phase aimed at checking the functional software that has been made, and product maintenance. In this study, the pedagogia dictionary website was validated by expert judgment and the results were in accordance with the assessment criteria so that it could be tested for the product. The product trial results, at the product trial stage, the results are related to the usability testing according to 10 respondents. Where respondents rated the dictionary website pedagogia dictionary both in terms of usability testing in aspects of learnability, efficiency, memorability, errors, satisfaction is good. The usability testing results are a series of product trial results showing that there are several recommendations from respondents. So it can be concluded that the product is good to be an information search system in the form of a pedagogical dictionary. Furthermore, the product can be further developed and can be accessed by anytime and anywhere. 


\section{ACKNOWLEDGEMENT}

This research was funded by a research grant at the University of Indonesian Education in 2019.

\section{REFERENCES}

Almekhlafi, A. G., \& Abulibdeh, E. S. A. (2018). K-12 teachers' perceptions of Web 2.0 applications in the United Arab Emirates?. Interactive Technology and Smart Education.

Ball, L. H., \& Bothma, T. J. (2018). Establishing Evaluation Criteria For EDictionaries. Library Hi Tech.

Barham, K. (2017). The use of electronic dictionary in the language classroom: The views of language learners. Online Submission, 1-12.

Bughin, J., Corb, L., Manyika, J., Nottebohm, O., Chui, M., de Muller Barbat, B., \& Said, R. (2011). The impact of internet technologies: Search. McKinsey \& Company. High Tech Practice, 60.

Chaer, A. (2007). Leksikografi Indonesia. Jakarta: Rineka Cipta.

Dashtestani, R. (2013). EFL teachers' and students' perspectives on the use of electronic dictionaries for learning English. Call-Ej, 14(2), 51-65.

Eimhjellen, I. S. (2014). Web technologies in practice: the integration of web technologies by environmental organizations. Media, Culture and Society, 36(6), 845861. https://doi.org/10.1177/0163443714536075

Ellis, T. J., \& Levy, Y. (2010, June). A guide for novice researchers: Design and development research methods. In Proceedings of Informing Science \& IT Education Conference (InSITE), 10, 107-118.

Haslhofer, B., \& Isaac, A. (2011, September). data. europeana. eu: The europeana linked open data pilot. In International Conference on Dublin Core and Metadata Applications (pp. 94-104).

Heid, U., Prinsloo, D. J., \& Bothma, T. J. (2012). Dictionary and corpus data in a common portal: state of the art and requirements for the future. Lexicographica, 28(1), 269-292.

Loucky, J. P. (2010). Comparing electronic dictionary functions and use. CALICO Journal, 28(1), 156.

Nugroho, A. (2010). Rekayasa perangkat lunak berorientasi objek dengan metode USDP. Penerbit Andi.

Permendikbud No 66 Tahun 2013. Jakarta: Ministry of Education and Culture.

Pernice, K. (2014), “A link is a promise”, available at: www.nngroup.com/articles/linkpromise/ (accessed 18 October 2019). 
Pressman, R. (2015). Rekayasa Perangkat Lunak: Pendekatan Praktisi Buku 1. Yogyakarta: ANDI.

Rezaei, M., \& Davoudi, M. (2016). The Influence of Electronic Dictionaries on Vocabulary Knowledge Extension. Journal of Education and Learning, 5(3), 139. https://doi.org/10.5539/jel.v5n3p139

Richey, \& Klein. (2009). Design and Development Research. New York: Routledge.

Sawant, S. (2017). Free but authentic mobile dictionaries: pros and cons. Library Hi Tech News.

Sommerville, I. (2011). Software engineering 9th Edition. ISBN-10, 137035152.

Suyanto, A. H. (2009). Step by Step Web Design Theory and Practices. Yogyakarta: Andi Publisher.

Svensén, B. (2009). A handbook of lexicography. The Theory and Practice of Dictionary-Making.

Takkaç Tulgar, A. (2017). Dictionary Use of Undergraduate Students in Foreign Language Departments in Turkey at Present. Universal Journal of Educational Research, 5(12B), 51-57. https://doi.org/10.13189/ujer.2017.051406

Zheng, H., \& Wang, X. (2016). The Use of Electronic Dictionaries in EFL Classroom. $\begin{array}{llll}\text { Studies in } & \text { English } & \end{array}$ https://doi.org/10.22158/selt.v4n1p144

www.oxfordlearnersdictionaries.com

www.merriam-webster.com 